\title{
Pengaruh Sistem Rekrutmen Pendidik dan Tenaga Kependidikan Terhadap Mutu Pendidikan Yayasan Pendidikan dan Sosial Pondok Pesantren Al-Fadl Banyuwangi
}

\author{
Abdi Fauji Hadiono ${ }^{1}$, Isti Faiyatul Inayah ${ }^{2}$ \\ e-mail: abdifauji777@gmail.com ${ }^{1}$, istiefaiya@gmail.com² \\ Prodi Manajemen Pendidikan Islam \\ Institut Agama Islam Darussalam Blokagung Banyuwangi
}

\begin{abstract}
The objectives of this research are (1) to examine the implementation of the recruitment system for educators and education personnel, (2) to examine the quality of education that has been achieved by the Education and Social Foundation of the Al-Fadl Banyuwangi Islamic Boarding School (3) to determine the effect of the recruitment system for educators and education personnel on education quality of the Education and Social Foundation of the AlFadl Banyuwangi Islamic Boarding School (4) to determine how much influence the recruitment system for educators and education personnel has on the quality of education. This research uses descriptive quantitative method. The population in this study were all educators and educational staff at the Al-Fadl Tegaldlimo Banyuwangi Education and Social Foundation, with a sample of 35 employees. Data collection techniques include observation, questionnaires and documentation. To measure the research variables used the product moment correlation formula. After analyzing the data, it is known that the results of $r$ count $=$ 0.697 if one consults the 5\% significance level price for the number of respondents (N) 35-2 = 33 indicates 0.344. So it can be said that rcount is greater than rtable or 0.697>0.344. The magnitude of the influence of the teacher recruitment system on the quality of education at the Al-Fadl Tegaldlimo Banyuwangi Education and Social Foundation is based on the calculation of the determinant coefficient of 49\%. This means that the teacher recruitment system and education variables contribute to an increase in the education quality variable by $49 \%$ which is between $41 \%-60 \%$, which is in the Enough category.
\end{abstract}

Keywords : Educators and Education Staff Recruitment System, Quality of Education

\begin{abstract}
Abstrak
Tujuan penelitian ini adalah (1) untuk mengkaji pelaksanaan sistem rekrutmen pendidik dan tenaga kependidikan, (2) untuk mengkaji mutu pendidikan yang telah dicapai Yayasan Pendidikan dan Sosial Pondok Pesantren Al-Fadl Banyuwangi (3) untuk mengetahui pengaruh sistem rekrutmen pendidik dan tenaga kependidikan terhadap mutu pendidikan Yayasan Pendidikan dan Sosial Pondok Pesantren Al-Fadl Banyuwangi (4) untuk mengetahui seberapa besar pengaruh sistem rekrutmen pendidik dan tenaga kependidikan terhadap mutu pendidikan. Penelitian ini menggunakan metode deskriptif kuantitatif. Populasi dalam penelitian ini adalah seluruh pendidik dan tenaga kependidikan di Yayasan Pendidikan dan Sosial Pondok Pesantren Al-Fadl Tegaldlimo Banyuwangi, dengan sampel 35 karyawan. Untuk teknik pengumpulan data yaitu meliputi observasi, angket dan dokumentasi. Untuk mengukur variabel penelitian digunakan rumus korelasi product moment. Setelah melakukan analisis data maka diketahui dengan hasil $r$ hitung $=0,697$ jika dikonsultasikan harga taraf signifikan 5\% untuk jumlah responden (N) 35-2= 33 menunjukkan 0,344. Sehingga bisa dikatakan $r_{\text {hitung }}$ lebih besar dari $r_{\text {tabel }}$ atau 0,697>0,344. Besarnya pengaruh sistem rekrutmen pendidik terhadap mutu pendidikan di Yayasan Pendidikan dan Sosial Pondok Pesantren Al-Fadl Tegaldlimo Banyuwangi berdasarkan hasil hitung koefisien determinan yaitu 49\%. Hal ini dapat diartikan bahwa variabel sistem rekrutmen pendidik dan kependidikan memberikan konstribusi peningkatan variabel mutu pendidikan sebesar 49\% yang berada diantara angka 41\%-60\% yaitu termasuk kategori Cukup.
\end{abstract}

Kata kunci : Sistem Rekrutmen Pendidik dan Tenaga Kependidikan, Mutu Pendidikan 


\section{A. Pendahuluan}

1. Latar Belakang

Dalam Undang-Undang Republik Indonesia Nomor 20 Tahun 2003 Tentang Sistem Pendidikan Nasional BAB XI Tentang Pendidik Tenaga Kependidikan Pasal 39 Ayat 1 dan 2 bahwa: (1) Tenaga kependidikan bertugas melaksanakan administrasi, pengelolaan, pengembangan, pengawasan, dan pelayanan teknis untuk menunjang proses pendidikan pada satuan pendidikan. (2) Pendidik merupakan tenaga profesional yang bertugas merencanakan dan melaksanakan proses pembelajaran, menilai hasil pembelajaran, melakukan pembimbingan dan pelatihan, serta melakukan penelitian dan pengabdian kepada masyarakat, terutama bagi pendidik pada perguruan tinggi.

Merujuk dari peraturan pemerintah tersebut tenaga pendidik kependidikan mempunyai tugas yang sangat besar dilembaga pendidikan terutama sekolah formal dari mulai mengajar hingga tahap evaluasi peserta didik, dari mengelola administrasi hingga pada pelayanan teknis yang digunakan sebagai penunjang proses berjalannya lembaga pendididkan. Tentu faktor ini tidak dapat disepelekan oleh lembaga pendidikan karena tenaga-tenaga inilah sumber daya yang mempunyai akal, berpengetahuan serta mempunyai banyak ketrampilan.

Lembaga pendidikan merupakan wadah dimana bertemunya seorang guru dan peserta didik guna untuk melakukan sebuah proses ditransformasi edukasi yang menjadikan kata ketidaktahuan menjadi lebih mengerti dan mengetahui, lembaga pendidikan juga merupakan lembaga yang diunggulkan dan dibutuhkan masyarakat. Sebagai lembaga pendidikan, suatu sekolah akan melakukan banyak aktifitas pendidikan bagi peserta didiknya serta melibatkan banyak komponen. Agar tercapainya lembaga pendidikan yang baik serta berdaya saing, maka komponen yang ada disekolah harus planning dengan manajemen yang baik pula.

Manajemen adalah suatu proses penyelenggaraan dari beberapa kegiatan sebagai wadah penerapan visi, misi dan tujuan serta sebagai kemampuan atau keterampilan seseorang yang berada pada jabatan tertentu 
untuk memperoleh hasil dalam rangka pencapaian tujuan dengan melalui kegiatan-kegiatan orang lain. Tentunya manajemen sangat diperlukan untuk mengelola lembaga pendidikan yang lebih terencana dan terkonsep. Pengembangan lembaga pendidikan dapat dilakukan dengan cara mengelola sumber daya yang sudah ada dalam lembaga pendidikan terkait.

Selain dari itu yang dapat dilakukan untuk mengelola efektivitas tenaga pendidik kependidikan adalah melalui pemaksimalan ketentuan yang sudah ditetapkan oleh pemerintah indonesia. Tetapi sebenarnya proses pengelolaan tenaga pendidik kependidikan dapat dilakukan dari awal perencanaan pendidikan yaitu pada proses pencarian tenaga pendidik kependidikan, cara yang biasanya dilakukan yaitu: Rekrutmen calon tenaga kerja, seleksi serta penempatan. Rekrutmen ialah suatu proses mencari, menemukan, dan menarik calon tenaga kerja yang nantinya akan dipekerjakan dalam suatu organisasi atau lembaga pendidikan itu sendiri.

Efektivitas sumber daya manusia pada suatu lembaga pendidikan akan sangat berpengaruh pada mutu pendidikan sekolah, sehingga jika prinsip-prinsip pengelolaan manajemen tenaga pendidik kependidikan dioptimalkan sesuai ketentuan yang telah dipaparkan oleh Dinas Pendidikan maka akan sangat mungkin berpengaruh pada tujuan pendidikan nasional itu sendiri.

Menurut Dessler (1997) dalam Sutrisno (2015: 05),

"Manajemen sumber daya manusia dapat diidentifikasikan sebagai suatu kebijakan dan praktek yang dibutuhkan seseorang yang menjalankan aspek 'orang' atau sumber daya manusia dari posisi seorang manajemen, meliputi perekrutan, penyaringan, pelatihan, pengimbalan dan penilaian. Yang paling diutamakan dalam proses pengelolaan kualitas sumber daya manusia adalah melalui proses rekrutmen. Rekrutmen merupakan suatu cara untuk mencari dan menarik calon tenaga kerja yang nantinya akan dipekerjakan pada organisasi terkait".

Mutu Pendidikan di Indonesia saat ini masih rendah dan berada di bawah Negara-negara ASEAN lainnya. Saat ini indonesia berada di tingkat 5 dari sekitar 10 negara yang ada di ASIA Tenggara. Tetapi disisilain, Indonesia mampu menampilkan prestasinya dalam berbagai kompetisi 
internasional. Pelaksanaan pendidikan yang berkualitas akan mendorong terwujudnya peserta didik berprestasi dan cerdas. Kunci utama pendidikan yang berkualitas adalah kinerja guru dan karyawan sekolah dalam melaksanakan tugas dan fungsinya sebagai seorang tenaga pendidik maupun tenaga kependidikan.

Kualitas pendidikan atau mutu pendidikan mempunyai peran penting sebagai output lembaga pendidikan. Mutu pendidikan akan terjamin jika sumber daya manusia mampu mengelola manajemen dengan sebaik mungkin. Dengan meningkatnya pengelolaan yang baik bagi mutu pendidikan maka suatu lembaga pendidikan akan dapat dikatakan sebagai lembaga pendidikan yang bermutu. Seperti yang dikatakan Mulyasana (2011: 120) bahwa:

"Pendidikan bermutu lahir dari sistem perencanaan yang baik (good planning system) dengan materi dan sistem kelola yang baik (good govermen system) dan disampaikan oleh guru yang baik (good teacher) dengan komponen pendidikan yang bermutu, khususnya guru".

Upaya yang dilakukan untuk peningkatan mutu pendidikan sekolah sebenarnya sudah ditentukan pada Standar Pendidikan Nasional. Standar Pendidikan Nasional ini meliputi beberapa standar diantaranya: Standar kompetensi lulusan, standar isi, standar proses, standar pendidik dan tenaga kependidikan, standar sarana dan prasarana, standar pengelolaan, standar pembiayaan, dan standar penilaian. Standar Nasional berfungsi sebagai sarana peningkatan dan penjaminan mutu pendidikan. Mutu pendidikan menurut Permendiknas nomor 63 tahun 2009 adalah tingkat kecerdasan kehidupan anak bangsa yang dapat diraih dari penerapan Sistem Pendidikan Nasional. Bukan hanya mutu yang perlu dibahas dalam proses pengambilan keputusan pendidikan, namun juga perlu ditetapkan penjaminan mutu pendidikan.

"Semua program pendidikan pada hakikatnya harus bisa diarahkan pada pencapaian mutu" (Qomar, 2010:203). Mutu pendidikan ada yang berupa Akademik dan Non Akademik, pencapaian mutu pendidikan dalam konteks akademik yaitu, seperti: rata-rata nilai siswa dapat diterima 
diperguruan tinggi negeri, rata-rata umum nilai siswa SMA/sederajat. Sedangkan yang berupa non akademik seperti, akreditasi sekolah yang berstatus "A", piagam perhargaan, kejuaraan lomba ekstrakurikuler dan lain sebagainya. Sehingga, jika suatu lembaga pendidikan menerapkan sistem rekrutmen yang efektif terhadap tenaga pendidik dan kependidikan tentu akan berdampak positif pada mutu pendidikan sekolah. Sub sistem tenaga kependidikan merupakan salah satu hal yang sangat penting untuk dapat meningkatkan mutu pendidikan.

Pada kenyataan yang ada dilapangan yaitu pada Yayasan Pendidikan Islam Al-Fadl Tegaldlimo Banyuwangi penulis mengamati bahwasanya sistem rekrutmen yang ada pada salah satu sekolah yang ada di Yayasan tersebut sudah dapat dikatakan baik, namun yang masih minim dalam peningkatan mutu. Karena masih sedikit prestasi akademik dan non akademik yang didapatkan. Serta masih sedikit output yang mampu untuk masuk pada perguruan tinggi negeri yang ada di Indonesia khususnya di Jawa Timur. Oleh karena itu, apakah sistem rekrutmen linear dengan mutu pendidikan.

2. Rumusan Masalah

1) Bagaimana sistem rekrutmen pendidik dan tenaga kependidikan Yayasan Pendidikan dan Sosial Pondok Pesantren Al-Fadl Tegaldlimo Banyuwangi?

2) Bagaimana mutu pendidikan di Yayasan Pendidikan dan Sosial Pondok Pesantren Al-Fadl Tegaldlimo Banyuwangi?

3) Adakah pengaruh sistem rekrutmen pendidik dan tenaga kependidikan terhadap mutu pendidikan di Yayasan Pendidikan dan Sosial Pondok Pesantren Al-Fadl Tegaldlimo Banyuwangi?

4) Seberapa besar pengaruh sistem rekrutmen pendidik dan tenaga kependidikan terhadap mutu pendidikan di Yayasan Pendidikan dan Sosial Pondok Pesantren Al-Fadl Tegaldlimo Banyuwangi? 
3. Tujuan Masalah

1) Untuk mengetahui sistem rekrutmen pendidik dan tenaga kependidikan di Yayasan Pendidikan dan Sosial Pondok Pesantren Al-Fadl Tegaldlimo Banyuwangi.

2) Untuk mengetahui mutu pendidikan di Yayasan Pendidikan dan Sosial Pondok Pesantren Al-Fadl Tegaldlimo Banyuwangi.

3) Untuk mengetahui pengaruh sistem rekrutmen pendidik dan tenaga kependidikan terhadap mutu pendidikan di Yayasan Pendidikan dan Sosial Pondok Pesantren Al-Fadl Tegaldlimo Banyuwangi.

4) Untuk mengetahui seberapa besar pengaruh sistem rekrutmen tenaga pendidik dan kependidikan terhadap mutu pendidikan di Yayasan Pendidikan dan Sosial Pondok Pesantren Al-Fadl Tegaldlimo Banyuwangi.

4. Manfaat Penelitian

1) Secara Teoritis

Sebagai pengetahuan mengenai sistem rekrutmen pendidik dan tenaga kependidikan pada mutu pendidikan serta bagaimana pengaruhnya

2) Secara Praktis

Hasil penelitian ini mampu menjadi bahan pertimbangan bagi lembaga pendidikan Islam Yayasan Al-Fadl Tegaldlimo dalam meningkatkan sumber daya manusia maupun mutu pendidikannya, serta sebagai acuan untuk peneliti selanjutnya yang meneliti tema yang sama dengan kajian lebih mendalam.

\section{B. Landasan Teori}

\section{Pengertian Sistem Rekrutmen}

Khusnuridlo (2013: 102) rekrutmen tenaga pendidik dan kependidikan didefinisikan sebagai alat untuk mencari atau mengadakan calon tenaga pendidik dan kependidikan yang berkualitas dan potensial sehingga sekolah dapat menyeleksi orang-orang yang sesuai dengan harapan sekolah. Dalam pandangan Islam proses rekrutmen merupakan persoalan yang krusial karena proses rekrutmen berpengaruh pada hasil kerja dan pencapaian tujuan organisasi. Islam juga menyatakan bahwasanya proses rekrutmen 
harus dilakukan dengan benar dan baik agar tujuan rekrutmen untuk mendapatkan karyawan yang pantas dan patut dapat tercapai. Pernyataan ini ditegaskan dalam Al-Qur'an surah Al-Qashash ayat 26 sebagai berikut:

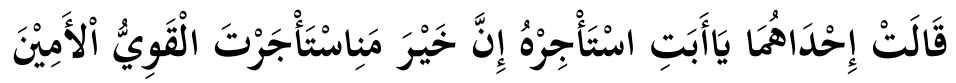

Artinya: " Dan salah seorang dari kedua (perempuan) itu berkata: "Wahai Ayahku! Jadikanlah ia sebagai orang yang bekerja (pada kita), sesungguhnya orang yang paling baik yang engkau ambil sebagai pekerja (pada kita) ialah orang yang kuat dan dapat dipercaya".

Ayat tersebut menerangkan bahwa karyawan yang dipekerjakan dalam dunia kerja apapun adalah karyawan yang kuat, yang mampu dan dapat dipercaya untuk kelangsungan proses pengembangan perusahaan ataupun lembaga-lembaga pendidikan. Dikatakan kuat yaitu seseorang yang memiliki fisik yang sehat jasmani dan rohani, karena dengan fisik yang kuat karyawan dapat melaksanakan tugas dengan baik sehingga nantinya dapat dipertanggung jawabkan. Berdasarkan pernyataan diatas sistem rekrutmen merupakan perangkat yang digunakan untuk mencari, menarik dan menemukan pelamar-pelamar atau para calon pegawai yang berkualitas serta mampu untuk dipekerjakan dalam lembaga pendidikan sehingga mampu mewujudkan sumber daya manusia yang efektif, efisien dan berkualitas.

Terdapat pernyataan yang ada didalam buku Khusnudhori tentang apa saja yang dilakukan dalam proses rekrutmen yaitu meliputi proses rekrutmen, seleksi dan yang terakhir adalah penempatan. Seleksi adalah suatu kegiatan untuk menentukan dan memilih dari beberapa calon tenaga kerja yang sesuai kriteria persyaratan pegawai perusahaan atau organisasi untuk ditempatkan pada posisi yang sedang kosong atau sedang membutuhkan tenaga kerja baru, seleksi dilakukan untuk mencari calon karyawan berkualitas dan berpotensi untuk mengisi jabatan yang kosong; Dapat mengurangi tingkat absensi kehadiran dan turnover karyawan; Menciptakan seorang karyawan yang cakap sebagai penunjang kesuksesan di satu lingkungan budaya (Siagian, 2015: 53).

Sedangkan penempatan menurut Hasibuan dalam Arifin dkk (2015: 75), "penempatan SDM adalah tindak lanjut dari proses seleksi, yaitu 
menempatkan calon karyawan yang diterima (lulus seleksi) untuk jabatan/pekerjaan yang membutuhkannya sekaligus mendelegasikan authority kepada orang tersebut".

Adapun macam-macam jenis penempatan pegawai yaitu:

a) Promosi

Promosi adalah pemindahan karyawan dari satu pekerjaan ke pekerjaan lain yang lebih tinggi dengan tanggung jawab dan penghasilan yang lebih tinggi pula

b) Mutasi/ Alih Tugas

Mutasi adalah pemindahan karyawan dari satu pekerjaan ke pekerjaan yang lain namun tetap pada posisi yang sederajat, dengan tanggung jawab dan penghasilan yang relatif sama

c) Demosi

Demosi adalah pemindahan karyawan dari satu pekerjaan ke pekerjaan yang lain yang lebih rendah, pemindahan ini biasanya dilakukan sebagai sanksi kepada karyawan atas pekerjaan dimasa sebelumnya.

\section{Pengertian Pendidik dan Tenaga Kependidikan}

Dalam sebuah lembaga pendidikan, manajemen sumber daya manusia juga merupakan unsur yang sangat penting. Yang dimaksud sebagai sumber daya manusia di dalam dunia pendidikan adalah pendidik dan tenaga kependidikan.

Tenaga pendidik ialah seseorang yang sering disebut dengan nama "guru" dan bertugas sebagai seseorang yang melakukan proses pembelajaran, penilaian hingga proses evaluasi peserta didik. Ismaya (2015: 107-108) pendidik merupakan tenaga kependidikan yang berkualifikasi sebagai guru, dosen, konselor, pamong belajar, tutor, instruktur, fasilitator, dan sebutan yang lain sebagaimana kekhususannya.

Sedangkan tenaga kependidikan adalah anggota masyarakat yang mengabdi di Lembaga pendidikan serta bertugas menyelenggarakan proses pendidikan seperti, melakukan administrasi, mengawasi, melayani, mengelola dan melakukan pelaksanaan pendidikan sekolah baik pada 
kegiatan makro atau mikro. Menurut Aliyyah (2018: 4) dalam bukunya Pengelolaan Pendidikan dan Tenaga Kependidikan mengatakan bahwa:

"Tenaga Kependidikan adalah tenaga-tenaga (personil) yang berkecimpung didalam lembaga atau organisasi pendidikan yang memiliki wawasan pendidikan (memahami falsafah dan ilmu pendidikan) dan melakukan kegiatan pelaksanaan pendidikan (mikro atau makro) atau penyelenggaraan pendidikan".

Sehingga jika disimpulkan akan menghasilkan sebuah pernyataan sebagai berikut:

1) Tenaga pendidik ialah : seseorang yang berada didalam lembaga pendidikan dan lebih sering disebut dengan guru, dosen, tutor dan lain sebagainya. Sebagai seorang yang dipercaya untuk mengembangkan kemampuan peserta didik.

2) Tenaga kependidikan ialah : seseorang yang berada didalam lembaga pendidikan serta bertugas sebagai penyelenggara pendidikan baik yang bersifat mikro ataupun makro. Profesi ini lebih sering melakukan aktifitasnya didalam kantor seperti Kepala sekolah, Waka. Kepala sekolah, Waka. Bidang kurikulum, Waka. Bidang kesiswaan, Waka. Bidang sarana prasarana, Waka. Bidang pelayanan kusus serta profesi lain yang beroperasi untuk kemajuan pendidikan.

Menurut Nur Aedi (2016: 12) kompetensi yang harus dimiliki pendidik antara lain: Kompetensi kepribadian, Kompetensi sosial, Kompetensi pedagogik, Kompetensi profesional. Sedangkan kompetensi yang harus dimiliki oleh tenaga kependidikan sesuai dengan Permendiknas No. 254 Tahun 2008, antara lain: Kompetensi kepribadian, Kompetensi sosial, Kompetensi teknis, Kompetensi manajerial.

3. Pengertian Mutu Pendidikan

Peter dan Nancy dalam Sallis (2012: 29) mengatakan pengertian "mutu adalah sebuah hal yang berhubungan dengan gairah dan harga diri". Tetapi menuru Qomar (2007: 204) dalam bukunya Manajemen Pendidikan Islam "Mutu Pendidikan adalah kemampuan lembaga pendidikan dalam mendayagunakan sumber-sumber pendidikan untuk meningkatkan kemampuan belajar siswa”. 
Mulyasana (2011: 120) menjelaskan "pendidikan bermutu adalah pendidikan yang sejatinya mampu melakukan proses pematangan kualitas peserta didik yang kemudian dikembangkan dengan cara membebaskan peserta didik dari ketidaktahuan, ketidakmampuan, ketidakberdayaan, ketidakbenaran, ketidakjujuran, dan dari buruknya akhlak dan keimanan.

Jadi mutu pendidikan adalah gambaran dan karakteristik menyeluruh atas pencapaian suatu hal dengan maksimal secara internal maupun eksternal baik kualitas maupun kuantitas guna untuk menunjang perkembangan sumber daya manusia agar memiliki kemampuan belajar yang tinggi sehingga nantinya mampu membentuk peserta didik yang berpengetahuan luas, serta berada dalam kepribadian yang berbudi pekerti baik dalam akhlak maupun keimanan.

Sagala dalam Fathurrohman dan Sulistyorini (2012: 55) menyatakan, bahwa lembaga pendidikan dapat dikatakan bermutu jika prestasi kususnya prestasi peserta didik, menunjukkan pencapaian yang tinggi dalam; (1) prestasi akademik meliputi nilai rapor siswa, serta nilai kelulusan yang menunjukkan kategori baik dan memenuhi standar yang telah ditentukan oleh pemerintah, (2) nilai nilai kejujuran, ketaqwaan, kesopanan, (3) prestasi non akademik, meliputi pencapaian dalam; bertanggung jawab tinggi, mampu mengapresiasi nilai-nilai budaya, berketrampilan.

Mutu merupakan realisasi dari ajaran ihsan, yaitu berbuat baik kepada sesame disebabkan Allah telah berbuat baik kepada manusia dengan aneka kenikmatan-Nya, dan setiap manusia dilarang untuk melakukan kerusakan dimuka bumi. Pernyataan ini sebagaimana termaktub dalam al-Qur'an surah al-Qashash (28) : 77.

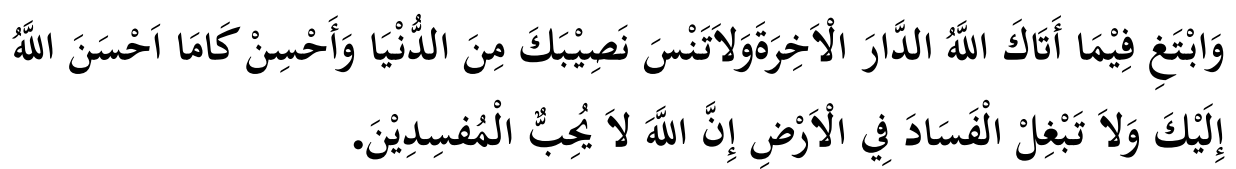

Artinya: "Carilah pada apa yang telah dianugerahkan Allah kepadamu (kebahagiaan) negeri akhirat, dan janganlah kamu melupakan bahagiamu dari (kenikmatan) duniawi dan berbuat baik (kepada orang lain) sebagaimana Allah telah berbuat baik kepadamu, dan janganlah kamu berbuat kerusakan di (muka) bumi. 
Sesungguhnya Allah tidak menyukai orang-orang yang berbuat kerusakan.

Dalam surah di atas dijelaskan bahwa Allah menyuruh manusia untuk mencari apapun yang telah dianugerahkan untuk kebahagiaan dunia maupun akhirat, serta selalu berbuat baik kepada sesame manusia. Dan Allah melarang setiap manusia untuk berbuat kerusakan di muka bumi ini. Artinya sesungguhnya Allah telah memberikan apapun yang dibutuhkan manusia, untuk mencapai mutu pendidikan yang sesuai keinginan lembaga pendidikan maka haruslah selalu berusaha untuk mengembangkan kualitas lembaga tersebut. Karena setiap usaha tidak akan menghianati setiap hasil yang didapat sebagaimana yang telah Allah firmankan pada surah di atas. Dengan menjadi pelayan yang baik bagi para murid, serta menjalin hubungan yang baik dengan wali murid agar lembaga pendidikan mengetahui apa yang masyarakat inginkan bagi setiap lulusannya nanti.

Mutu memiliki beberapa karakter seperti yang dikatakan Usman sebagaimana dikutip Fathurroman dan Sulistyorini (2012: 57) mutu memiliki 13 karakteristik sebagai berikut:

a) Kinerja; berkaitan dengan aspek fungsional sekolah.

b) Waktu ajar; selesai tepat waktu

c) Handal; pelayanan prima bertahan lama

d) Daya tahan; tahan banting

e) Indah

f) Hubungan manusiawi; menjunjung tinggi nilai moral dan profesionalisme

g) Mudah dalam penggunaan; sarana prasarana yang dipakai

h) Bentuk khusus; keunggulan tertentu

i) Standar tertentu; memenuhi standar tertentu

j) Konsisten; keajegan, konstan, atau stabil

k) Seragam; tanpa variasi, tidak tercampur

1) Mampu melayani; mampu memberi pelayanan prima

m) Ketepatan; ketepatan dalam pelayanan 
4. Penelitian Terkait

1) Penelitian oleh Dwi Utami, 2016 dengan judul " Manajemen Rekrutmen Tenaga Pendidik dalam Peningkatan Kualitas Pendidikan di Sekolah Dasar Ta'mirul Islam Surakarta” jenis penelitian yang digunakan dalam penelitian ini yaitu deskriptif kualitatif, dan untuk teknik analisis data menggunakan model analisis interaktif yang meliputi pengumpulan data, reduksi data, penyajian data dan penarikan kesimpulan. Hasil penelitian menunjukkan: (a) Manajemen rekrutmen tenaga pendidik dalam peningkatan kualitas pendidikan di SD Ta ${ }^{e e}$ mirul Islam Surakarta telah terlaksana dengan baik. (b) Dalam rekrutmen kepala sekolah dan yayasan berperan penting dalam pengawasan untuk menghindari adanya kemungkinan penyelewengan atau penyimpanan atas tujuan yang akan dicapai.

2) Penelitian oleh Putri Amalia, 2010 dengan judul penelitian "Strategi Rekrutmen Tenaga Pendidik dan Kependidikan pada SDIT Darul Muttaqien Parung Bogor" jenis penelitian yang digunakan adalah penelitian deskriptif kualitatif, teknik pengumpulan data yang digunakan yaitu teknik wawancara, observasi dan studi dokumentasi. Hasil penelitian ini mengungkapkan bahwa strategi rekrutmen yang dilakukan oleh kepala sekolah sudah cukup baik. Kegiatan perekrutan ini dimulai dengan menganalisa kebutuhan SDM, keadaan jumlah siswa pada tahun berjalan serta perkiraan pada tahun selanjutnya sampai pada penempatan pegawai baru. Dalam penerapannya, metode ini sudah termasuk efektif. Keefektifitasan ini dibuktikan dengan tidak adanya guru yang mangkir dari tugas yang diberikan.

Keterkaitan dari dua penelitian ini adalah jika yang dilakukan sebelumnya berupa manajemen rekrutmen dan strategi rekrutmen sedangkan pada penelitian yang akan peneliti lakukan ini ingin mengetahui sistem rekrutmen yang berpengaruh pada mutu pendidikan untuk mengetahui sejauhmana sistem rekrutmen tersebut benar-benar dibutuhkan, sedang metode yang digunakanpun juga berbeda, pada penelitian saudari Dwi Utami dan saudari Putri Amalia ini menggunakan 
pendekatan deskriptif kualitatif sedangkan pada penelitian ini menggunakan penelitian kuantitatif dan untuk teknik analisis data menggunakan analisis Produck Moment. Tempat yang akan penulis gunakan sebagai objek penelitianpun juga berbeda dengan penelitian yang terkait tersebut.

\section{Metode Penelitian}

Jenis penelitian ini deskriptif kuantitatif. Penelitian ini dilakukan di Yayasan Pendidikan dan Sosial Pondok Pesantren Al-Fadl Tegaldlimo Banyuwangi tepatnya pada karyawan sekolah formal yang ada di Yayasan Al-Fadl yang dengan responden 40 karyawan. Untuk pengujian skor instrumen digunakan uji validitas dan uji reliabilitas. Prosedur pengumpulan data dalam penelitian ini yaitu: Observasi, Angket, Dokumentasi. Analisis data yang digunakan yaitu analisis kualitatif dan analisis kuantitatif. Analisis kualitatif dalam penelitian ini digunakan untuk mengetahui dan menggambarkan mengenai keadaan variable, Penggambaran dari kedua variabel ini dinyatakan dalam bentuk prosentase yang selanjutnya ditafsirkan dengan label kriteria yang telah dibuat. Sedangkan Dalam penelitian ini, analisis data yang digunakan adalah analisis Statistik. Guna untuk mengetahui ada tidaknya hubungan antara dua variabel, maka peneliti menggunakan Korelasi Product Moment.

\section{Hasil Penelitian}

1) Uji Validitas

Uji validitas merupakan suatu cara untuk menguji apakah instrumen yang digunakan dapat mengukur apa yang seharusnya diukur dan tidak. Dalam hal uji validitas digunakan dengan pengujian t-test, yaitu dengan membandingkan antara $t$ hitung dengan $t$ tabel. Jika $t$ hitung lebih besar dari $\mathrm{t}$ tabel maka perbedaan yang ada adalah signifikan, sehingga instrumen bisa dinyatakan valid. Tingkat signifikansi pada uji t adalah 0,05 atau 5\%. Hasil uji validitas terhadap instrumen penelitian ini disajikan pada tabel berikut : 
Tabel 1

Hasil Uji Validitas

\begin{tabular}{|c|c|c|c|c|}
\hline No. & Item & Correted Item- & r tabel $(5 \%)$ & Kriteria \\
\hline 1 & $\mathrm{X} 1$ & 0,459 & 0,344 & Valid \\
\hline 2 & $\mathrm{X} 2$ & 0,434 & 0,344 & Valid \\
\hline 3 & X3 & 0,455 & 0,344 & Valid \\
\hline 4 & $\mathrm{X} 4$ & 0,623 & 0,344 & Valid \\
\hline 5 & $\mathrm{X} 5$ & 0,388 & 0,344 & Valid \\
\hline 6 & X6 & 0,515 & 0,344 & Valid \\
\hline 7 & $\mathrm{X} 7$ & 0,551 & 0,344 & Valid \\
\hline 8 & $\mathrm{X} 8$ & 0,522 & 0,344 & Valid \\
\hline 9 & X9 & 0,650 & 0,344 & Valid \\
\hline 10 & $\mathrm{X} 10$ & 0,407 & 0,344 & Valid \\
\hline 11 & $\mathrm{X} 11$ & 0,476 & 0,344 & Valid \\
\hline 12 & $\mathrm{X} 12$ & 0,585 & 0,344 & Valid \\
\hline 13 & X13 & 0,355 & 0,344 & Valid \\
\hline 14 & $\mathrm{X} 14$ & 0,370 & 0,344 & Valid \\
\hline 15 & $\mathrm{X} 15$ & 0,375 & 0,344 & Valid \\
\hline 16 & $\mathrm{Y} 1$ & 0,465 & 0,344 & Valid \\
\hline 17 & $\mathrm{Y} 2$ & 0,344 & 0,344 & Valid \\
\hline 18 & Y3 & 0,456 & 0,344 & Valid \\
\hline 19 & Y4 & 0,613 & 0,344 & Valid \\
\hline 20 & Y5 & 0,541 & 0,344 & Valid \\
\hline 21 & Y6 & 0,575 & 0,344 & Valid \\
\hline 22 & Y7 & 0,436 & 0,344 & Valid \\
\hline 23 & Y8 & 0,610 & 0,344 & Valid \\
\hline 24 & Y9 & 0,345 & 0,344 & Valid \\
\hline 25 & Y10 & 0,667 & 0,344 & Valid \\
\hline 26 & Y11 & 0,543 & 0,344 & Valid \\
\hline 27 & Y12 & 0,349 & 0,344 & Valid \\
\hline 28 & Y13 & 0,513 & 0,344 & Valid \\
\hline 29 & Y14 & 0,422 & 0,344 & Valid \\
\hline 30 & Y15 & 0,589 & 0,344 & Valid \\
\hline
\end{tabular}

Sumber Data : Olahan Peneliti

Berdasarkan data pada tabel di atas, diketahui bahwa semua pengujian terhadap instrumen variabel $\mathrm{X}$ maupun variabel $\mathrm{Y}$ menunjukkan bahwa seluruh pertanyaan yang diajukan adalah Valid. Nilai $\mathrm{r}$ tabel untuk tingkat signifikan 0,05 dan dk 35-2 adalah 0,344. Dengan demikian semua butir pertanyaan dalam kuesioner tersebut dapat dipercaya dan dapat digunakan untuk mengumpulkan data yang diperlukan. 
2) Uji Reliabilitas

Sebuah instrumen mampu dikatakan reliabel apabila instrumen tersebut digunakan untuk mengukur gejala atau objek yang sama lebih dari satu kali akan diperoleh hasil pengukuran yang sama. Pengujian reliabilitas dilakukan dengan menggunakan teknik Cronbach Alpha. Suatu data dikatakan reliabel apabila memenuhi persyaratan nilai Cronbach Alpha > 0,6. Hasil uji reliabilitas terhadap data penelitian disajikan pada tabel berikut ini :

Tabel 2

Hasil Uji Reliabilitas

\begin{tabular}{|c|c|c|c|}
\hline No & Variabel & Cronbach Alpha & Kriteria \\
\hline 1 & $\begin{array}{c}\text { Sistem rekrutmen pendidik dan } \\
\text { tenaga kependidikan }\end{array}$ & 0,731 & Kuat \\
\hline 2 & Mutu pendidikan & 0,773 & Kuat \\
\hline
\end{tabular}

Sumber Data : Olahan Peneliti

Berdasarkan hasil analisis pada data di atas menunjukkan bahwa nilai Cronbach Alpha dari masing-masing variabel ada pada kriteria kuat. Dengan demikian dapat disimpulkan bahwa semuaalat ukur yang digunakan dalam penelitian ini adalah Reliabel.

3) Analisis Data

Dari data $(\mathrm{X})$ yang peneliti olah, responden yang memiliki skor lebih dari 57 berjumlah 19 responden sedangkan yang mempunyai skor dibawah 57 berjumlah 16 dimana prosentasenya sebagai berikut :

Jumlah Presentase $=\frac{n}{N} \times 100 \%$

Jumlah Presentase $=\frac{19}{35} \times 100=54,28 \%$

Jika dilihat dari perolehan data di atas dapat dinyatakan bahwa variabel (X) yaitu Sistem Rekrutmen Pendidik dan Tenaga Kependidikan di Yayasan Pendidikan dan Sosial Pondok Pesantren Al-Fadl Tegaldlimo Banyuwangi termasuk kategori Cukup.

Sedangkan hasil angket variabel Y adalah sebagai berikut : 
Dari data yang telah di olah, responden yang memiliki skor sama dengan atau lebih dari $(\geq) 64$ berjumlah 21 sedangkan responden yang memiliki skor kurang dari $(<)$ berjumlah 14 . Dimana presentasenya sebagai berikut:

Nilai Presentase $=\frac{n}{N} \times 100=\frac{21}{35} \times 100=60 \%$

Jika dilihat dari hasil perolehan di atas maka dapat dinyatakan bahwa variabel (Y) yaitu Mutu Pendidikan di Yayasan Pendidikan dan Sosial Pondok Pesantren Al-Fadl Tegaldlimo Banyuwangi Tahun Pembelajaran 2018/2019 termasuk kategori Cukup.

4) Analisis korelasi $X$ dan $Y$

Sebagaimana yang telah di sajikan pada bagian sebelumnya bahwa penelitian ini menggunakan 1 variabel bebas dan 1 variabel terikat. Untuk keperluan analisis kuantitatif akan digunakan teknik korelasi Product Moment

Langkah 3 : memasukkan data kedalam rumus product moment

$$
\begin{aligned}
& r_{x y}=\frac{n \sum x y-\left(\sum x\right)\left(\sum y\right)}{\sqrt{\left\{n \sum x^{2}-\left(\sum x\right)^{2}\right\}}\left\{n \sum y^{2}-\left(\sum y\right)^{2}\right\}} \\
& r_{x y}=\frac{35.129677-(2009)(22477)}{\sqrt{\left\{35.116543-(2009)^{2}\right\}}\left\{35.145077-(2247)^{2}\right\}} \\
& r_{x y}=\frac{4538695-4514223}{\sqrt{\{4079005-4036081\}}\{5077695-5049009\}} \\
& r_{x y}=\frac{24472}{\sqrt{\{42924\}}\{28686\}} \\
& r_{x y}=\frac{24472}{\sqrt{1231317864}} \\
& r_{x y}=\frac{24472}{35090,13} \\
& r_{x y}=0,697
\end{aligned}
$$

5) Pengujian Hipotesis

Hasil hitung berdasarkan rumus rxy product moment dengan jumlah responden 35 diperoleh nilai 0,697, sedangkan nilai rxy tabel dengan jumlah responden 35 pada taraf signifikan 5\% diperoleh $\mathrm{r}$ tabel $(\mathrm{dk}=\mathrm{n}-2=$ 
$35-2=33$ ) sehingga $\mathrm{r}$ tabel $=0,344$, sedangkan taraf signifikan $1 \%$ diperoleh $\mathrm{r}$ tabel $=0,443$, sehingga rxy hitung 0,697 lebih besar dari rxy tabel taraf sig $5 \%$ bernilai 0,344 dan juga rxy tabel taraf $1 \%$ bernilai 0,443 . Dengan demikian Hipotesis Nol yang menyatakan "Tidak ada Pengaruh Sistem Rekrutmen Pendidik dan Tenaga Kependidikan Terhadap Mutu Pendidikan di Yayasan Pendidikan dan Sosial Pondok Pesantren Al-Fadl Tahun Pembelajaran 2018/2019" ditolak dan Hipotesis Alternatif yang berbunyi "Ada Pengaruh Sistem Rekrutmen Pendidik dan Tenaga Kependidikan Terhadap Mutu Pendidikan di Yayasan Pendidikan dan Sosial Pondok Pesantren Al-Fadl Tahun Pembelajaran 2018/2019" diterima.

\section{E. Pembahasan}

Setelah data didapatkan dan dianalisis menggunakan rumus korelasi product moment maka telah terbukti antara variabel $\mathrm{X}$ dan variabel $\mathrm{Y}$ terdapat hubungan, untuk lebih jelasnya dapat dikemukakan sebagai berikut :

a. Berdasarkan data variabel X diketahui mean jumlah skor 2009 dan juga mean (rata-rata) yang diperoleh adalah 57, maka dapat dikategorikan bagi responden yang mempunyai jumlah skor sama dengan atau lebih dari mean dikategorikan kuat (K). Bagi responden yang mempunyai jumlah skor kurang dari mean maka dikategorikan lemah (L). sehingga dari data tersebut diperoleh nilai skor diatas rata-rata berjumlah 19 dan di skor dibawah ratarata berjumlah 16. Dimana presentasenya sebagai barikut :

Jumlah Presentase $=\frac{19}{35} \times 100=54,28 \%$

Dengan demikian dapat dinyatakan bahwa variabel X yaitu Pengaruh Sistem Rekrutmen Pendidik dan Tenaga Kependidikan di Yayasan Pendidikan dan Sosial Pondok Pesantren Al-Fadl Tegaldlimo Banyuwangi Tahun Pembelajaran 2018/2019 termasuk kategori Cukup.

b. Berdasarkan data variabel X diketahui mean jumlah skor 2247 dan juga mean (rata-rata) yang diperoleh adalah 64, maka dapat dikategorikan bagi responden yang mempunyai jumlah skor sama dengan atau lebih dari mean 
dikategorikan kuat (K). Bagi responden yang mempunyai jumlah skor kurang dari mean maka dikategorikan lemah (L). sehingga dari data tersebut diperoleh nilai skor diatas rata-rata berjumlah 21 dan di skor dibawah ratarata berjumlah 14. Dimana presentasenya sebagai barikut :

Jumlah Presentase $=\frac{21}{35} \times 100=60 \%$

Dengan demikian dapat dinyatakan bahwa variabel $\mathrm{X}$ yaitu Mutu Pendidikan di Yayasan Pendidikan dan Sosial Pondok Pesantren Al-Fadl Tegaldlimo Banyuwangi Tahun Pembelajaran 2018/2019 termasuk kategori

\section{Cukup.}

c. Berdasarkan dari data yang ada, diketahui bahwa $r$ hitung sebesar 0,697 sedangkan nilai $\mathrm{r}$ tabel $(\mathrm{dk}=\mathrm{n}-2=35-2=33)$ sehingga $\mathrm{r}$ tabel $=0,344$. Karena $\mathrm{r}$ hitung lebih besar dari $\mathrm{r}$ tabel atau 0,697>0,344, maka disimpulkan bahwa ada hubungan yang signifikan antara variabel sistem rekrutmen pendidik dan tenaga kependidikan dengan variabel mutu pendidikan.

d. Besarnya pengaruh variabel $\mathrm{x}$ terhadap y berdasarkan hasil hitung koefisien determinan yaitu rxy hitung ${ }^{2} \mathrm{X} 100 \%=0,697^{2} \mathrm{X} 100 \%=49 \%$. Hal ini berarti variabel $\mathrm{X}$ memberikan kontribusi peningkatan variabel $\mathrm{Y}$ sebesar $49 \%$.

\section{F. Kesimpulan}

1. Sistem Rekrutmen Pendidik dan Tenaga Kependidikan di Yayasan Pendidikan dan Sosial Pondok Pesantren Al-Fadl Tegaldlimo Banyuwangi Tahun Pembelajaran 2018/2019 adalah sebesar 54,28\% kategori cukup.

2. Mutu Pendidikan di Yayasan Pendidikan dan Sosial Pondok Pesantren AlFadl Tegaldlimo Banyuwangi Tahun Pembelajaran 2018/2019 adalah sebesar $60 \%$ kategori cukup.

3. Ada pengaruh positif yang signifikan antara variabel sistem rekrutmen pendidik dan tenaga pendididkan terhadap variabel mutu pendidikan.

4. Besarnya pengaruh sistem rekrutmen pendidik terhadap mutu pendidikan di Yayasan Pendidikan dan Sosial Pondok Pesantren Al-Fadl Tegaldlimo 
Banyuwangi Tahun Pembelajaran 2018/2019 berdasarkan hasil hitung koefisien determinan sebesar $49 \%$.

\section{G. Daftar Pustaka}

Aedi, Nur. 2016. Manajemen Pendidik \& Tenaga Kependidikan. Yogyakarta: Gosyen Publishing.

Amalia, Putri. 2010. Strategi Rekrutmen Tenaga Pendidik dan Kependidikan pada Sekolah Dasar Ilmu Terpadu Darul Muttaqin. Jurnal Penelitian Universitas Negeri Islam Syarif Hidayatullah Jakarta.

Arifin, Miftahul dkk. 2015. Manajemen Sumber Daya Manusia. Surabaya: Kopertais press.

Arikunto, Suharsimi. 2010. Prosedur Penelitian (suatu pendekatan praktik). Jakarta: PT Rineka Cipta

Fathurrohman, Muhammad \& Sulistyorini. 2012. Implementasi Manajemen Peningkatan Mutu Pendidikan Islam. Yagyakarta: Teras

Khusnuridlo, Moh. 2013. STANDAR NASIONAL PENDIDIKAN Manajemen Tenaga Pendidik dan Kependidikan. Jember: STAIN Jember Press

Mulyasana, Dedy. 2011. Pendidikaan Bermutu dan Berdaya Saing. Bandung: PT Remaja Rosdakarya.

Sutrisno, Edy. 2017. Manajemen Sumber Daya Manusia. Jakarta: Kencana

Undang-undang Tentang SISDIKNAS (Sistem Pendidikan Nasional) No 20 Tahun 2003. Jogjakarta: Bening

Utami, Dwi. 2016. Manajemen Rekrutmen Tenaga Pendidik dalam Peningkatan Kualitas Pendidikan di Sekolah Dasar Ta'mirul Islam Surakarta. Jurnal Program Pasca Sarjana, (online) 